\title{
SEROPREVALENCE OF SYPHILIS IN HEALTHY BLOOD DONORS OF LAHORE DURING YEAR 2016 AND 2017; AN UPCOMING PROBLEM FOR PAKISTAN.
}

\footnotetext{
1. MBBS

House Officer

Mayo hospital, Lahore.

2. MBBS, FCPS

Assistant Professor

Department of Histopathology

Mayo Hospital, Lahore.

3. MBBS

House Officer

Mayo Hospital, Lahore.

4. MBBS

Final Year

5. MBBS

Final Year

6. B.Sc

Correspondence Address:

Dr. Sarmad Zahoor

Mayo hospital, Lahore.

drsarmadzahoor@gmail.com

Article received on:

17/06/2019

Accepted for publication:

25/10/2019
}

\begin{abstract}
Sarmad Zahoor ${ }^{1}$, Samreen Hameed², Waqas Iqbal ${ }^{3}$, Hafeez ur Rehman ${ }^{4}$, Muhammad Naveed ur Rehman ${ }^{5}$, Jamil Jaral ${ }^{6}$

ABSTRACT: Blood transfusion has been proven as a common cause for contracting infectious diseases with 1.5 million donors each year in Pakistan carrying $1 \%$ risk of transfusion transmitted infections. Syphilis is one of them whose seroprevalence has been increasing in recent years. Thus, evaluation of its seroprevalence will give information about current burden of the disease. Objectives: To determine seroprevalence of syphilis among healthy blood donors of Lahore to assess disease burden for year 2016 and 2017. Study Design: Retrospective single centre cross-sectional study. Setting: Tertiary care hospital (Mayo Hospital) in Lahore with a referral base from all over Pakistan but predominantly from the Punjab province. Period: Two years (from January 2016 to December 2017). Material \& Methods: The study was based on immunechromatographic assay of antibodies to Treponema pallidum in human serum using Nantong Egens Syphilis detection Kits. This is a qualitative test and provides rapid screening for syphilis in blood donors. Data was analyzed using SPSS 20 for prevalence study and mathematically for future prediction of its percentage. Results: A total of 76530 blood donors reported in the blood bank in two years. Out of these donors, 1720 were positive for TP antibody showing an overall percentage of 2.25\%, 755 were positive in 2016 \& 965 in 2017 with their percentages being $2.02 \%$ \& $2.46 \%$ respectively. Conclusion: Percentage of syphilis has increased in year 2016 and 2017. This needs to be reduced by taking preventive measures and education to masses. Further work up of the patients who were TP positive is required.
\end{abstract}

Key words: Blood Donors, Syphilis, Treponema Pallidum Antibody.

$\begin{aligned} \text { Article Citation: } & \text { Zahoor S, Hameed S, lqbal W, Hafeez ur Rehman, Naveed ur Rehman M, } \\ & \text { Jaral J. Seroprevalence of Syphilis in healthy blood donors of Lahore during } \\ & \text { year } 2016 \text { and 2017; An upcoming problem for Pakistan. Professional Med }\end{aligned}$
Article Citation: Zahoor S, Hameed S, lqbal W, Hafeez ur Rehman, Naveed ur Rehman M,
Jaral J. Seroprevalence of Syphilis in healthy blood donors of Lahore during
year 2016 and 2017; An upcoming problem for Pakistan. Professional Med
Article Citation: Zahoor S, Hameed S, lqbal W, Hafeez ur Rehman, Naveed ur Rehman M,
Jaral J. Seroprevalence of Syphilis in healthy blood donors of Lahore during
year 2016 and 2017; An upcoming problem for Pakistan. Professional Med J 2020; 27(1):138-142. DOI: 10.29309/TPMJ/2020.27.1.3823

\section{INTRODUCTION}

Blood transfusion, on one hand, has saved millions of lives, while on the other hand, it has also been proven as a cause for contracting infectious diseases. ${ }^{1,2}$ Each transfusion carries 1 percent likelihood of causing transfusion transmissible infections (TTIs). ${ }^{3}$ Thus, each and every transfusion has got a risk for spreading infectious diseases. ${ }^{5}$

In Pakistan, approximately 1.5 million people donate blood every year \& the number is increasing constantly. ${ }^{6,7}$ Transfusion of safe and healthy blood is a universal right and is also an indicator of high quality of a healthcare system. ${ }^{2,8}$ However in Pakistan problems encountered in this process are many with the most significant being lack of provision of proper services recommended by WHO, poverty and unavailability of resources because of majority of population living in rural areas..$^{9,10}$ Hence, it strictly demands improvements in infrastructure, proper training of the staff \& equipping of blood banks with all the required resources. ${ }^{11}$

An important disease which can be transmitted via blood is syphilis which is basically a sexually transmitted disease causes by Treponema pallidum, a spirochete. It can also be transmitted vertically from mother to child. ${ }^{12,13}$ Syphilis may either be manifested as asymptomatic or symptomatic. With its primary, secondary or tertiary stage). ${ }^{14,15}$ Its asymptomatic manifestation in blood makes it essential to properly screen the blood of healthy donors before being transfused to recipients, in order to prevent its transmission. 
Syphilis is a prevalent STD both in developed and developing countries and its prevalence has increased world widely \& in Pakistan as well. ${ }^{1,16,17}$ It is believed that the prevalence of an infection in blood donors may not truely reflect its prevalence in general population. It may falsely estimate disease prevalence because the blood donors mostly include young or middle aged males only and exclude elderly \& very young age groups. ${ }^{18,19}$ However it can give an idea about the disease burden in a population and can also aid in ensuring safe transfusion of blood \& blood products. ${ }^{20,21}$

In our search for literature about prevalence of syphilis in healthy donors of Pakistan, we found that the prevalence is increasing at a rapid pace. A survey conducted in Lahore at Shaukat Khanum Memorial Cancer Hospital showed an increasing percentage of its prevalence through 1996 to 2005 with maximum percentage being in year 2002. ${ }^{21}$ Two recent studies carried out in Lahore in 2012 \& 2014 depict an overall prevalence of $3.1 \%$ and $4.9 \%$ respectively. ${ }^{15,17}$ Data from other cities including Karachi \& Islamabad (two big cities of Pakistan) also portray an increasing prevalence of this disease. ${ }^{22,2,16}$ This demands that its prevalence in blood donors needs to be evaluated each year. Here, we have studied prevalence of Syphilis in healthy donors of Lahore for the year 2016 and 2017 with the aim to assess the disease burden and also to monitor the safety of blood transfusion which may form the basis of public policy.

\section{OBJECTIVES}

1. Seroprevalence of syphilis among the healthy donors during year 2016 and 2017 visiting a public tertiary care hospital

2. Assess disease burden in order to form public policy.

\section{METHODOLOGY}

\section{Study Design}

This is a retrospective single center cross sectional study.

\section{Setting}

This study was carried out at a tertiary care hospital (Mayo Hospital) in Lahore with a referral base from all over Pakistan but predominantly from the Punjab province.

\section{Sample Size}

Data of 76,530 healthy blood donors was collected from hospital blood bank for a period of two years (from January 2016 to December 2017). This study included healthy donors of age ranging from 18 to 55 years whereas all those below 18 and above 55 years of age were excluded. Moreover, the donors with $\mathrm{Hb}$ level less than $12 \mathrm{~g} /$ $\mathrm{dl}$ as well as high risk populations including drug abusers, diabetics and those with chronic kidney disease were also excluded.

\section{Lab Test}

The study was based on immunochromatographic assay of antibodies to Treponema Pallidum in human serum using Nantong Egens Syphilis detection Kits. This is a qualitative test and provides rapid screening for syphilis in blood donors.

After collecting donor samples, 3cc fresh blood was added to grey top vacutainers. The test was performed immediately after the serum was separated in the tube. 3 drops of serum using droppers provided in the kit were added to the well in device. Test results were read after 15 minutes.

Since the test was meant to determine the presence of antibodies to TP, there were 2 bars of TP antigen present on the device. The binding of antibody to its antigen resulted in a positive reaction which gave rise to pink line on device antigen area. Intensity of this colour was dependent on the quantity of antibody in that serum. Data was analyzed using SPSS 20 for finding prevalence and was analyzed mathematically to predict its future burden.

\section{RESULTS}

A total of 76530 blood donors reported to the blood bank in two years, 37,341 and 39,189 in 2016 \& 2017 respectively. Out of these 76,530 donors, 1720 were positive for TP antibody showing an overall percentage of $2.25 \%, 755$ were positive in 
2016 \& 965 in 2017 with their percentages being $2.02 \% \& 2.46 \%$ respectively. Seroprevalence of syphilis for the years 2016 and 2017 are also summarized in Tables-I \& II respectively.

\begin{tabular}{|c|c|c|c|c|}
\hline Year & Month & $\begin{array}{c}\text { Total } \\
\text { Screenings }\end{array}$ & $\begin{array}{c}\text { Tp } \\
+ \text { Ve }\end{array}$ & $\%$ \\
\hline 2016 & January & 3242 & 94 & 2.899445 \\
\hline & February & 3304 & 56 & 1.694915 \\
\hline & March & 3744 & 83 & 2.21688 \\
\hline & April & 3504 & 60 & 1.712329 \\
\hline & May & 3698 & 61 & 1.64954 \\
\hline & June & 3870 & 51 & 1.317829 \\
\hline & July & 3142 & 68 & 2.164227 \\
\hline & August & 3006 & 71 & 2.361943 \\
\hline & September & 2400 & 52 & 2.166667 \\
\hline & October & 2819 & 63 & 2.234835 \\
\hline & November & 2211 & 34 & 1.537766 \\
\hline & December & 2401 & 62 & 2.582257 \\
\hline Total & & 37341 & 755 & 2.021906 \\
\hline
\end{tabular}

Table-I. Seroprevalence of syphilis in healthy blood donors at Mayo Hospital Lahore for the year 2016.

\begin{tabular}{|c|c|c|c|c|}
\hline Year & Month & $\begin{array}{c}\text { Total } \\
\text { Screenings }\end{array}$ & $\begin{array}{c}\text { Tp } \\
+\mathbf{v e}\end{array}$ & $\%$ \\
\hline 2017 & January & 3382 & 88 & 2.602011 \\
\hline & February & 3385 & 67 & 1.979321 \\
\hline & March & 3691 & 71 & 1.923598 \\
\hline & April & 3221 & 91 & 2.82521 \\
\hline & May & 3182 & 82 & 2.576996 \\
\hline & June & 3143 & 73 & 2.322622 \\
\hline & July & 3052 & 68 & 2.228047 \\
\hline & August & 3319 & 89 & 2.681531 \\
\hline & September & 2997 & 110 & 3.670337 \\
\hline & October & 3319 & 91 & 2.74179 \\
\hline & November & 2912 & 56 & 1.923077 \\
\hline & December & 3586 & 79 & 2.203012 \\
\hline Total & & 39189 & 965 & 2.462426 \\
\hline
\end{tabular}

Table-II. Seroprevalence of syphilis in healthy blood donors at Mayo Hospital Lahore for the year 2017.

\begin{tabular}{|l|c|c|c|}
\hline & $\mathbf{2 0 1 6}$ & $\mathbf{2 0 1 7}$ & Overall \\
\hline Total Screenings & 37341 & 39189 & 76530 \\
\hline TP positive & & & \\
\hline Percentage & 755 & 965 & 1720 \\
\hline Total Screenings & $2.02 \%$ & $2.46 \%$ & $2.25 \%$ \\
\hline
\end{tabular}

Table-III. Overall seroprevalence for the years 2016 and 2017 respectively.

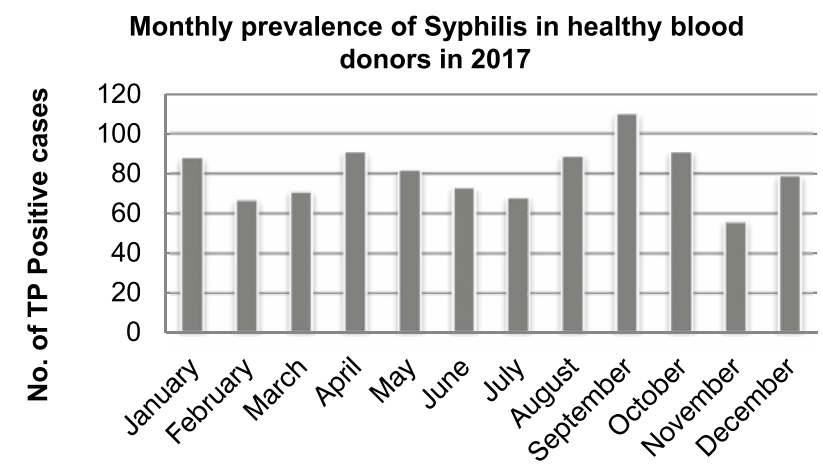

Figure-1

Comparison of percentage prevalence of syphilis amongst healthy blood donors in 2016 \& 2017

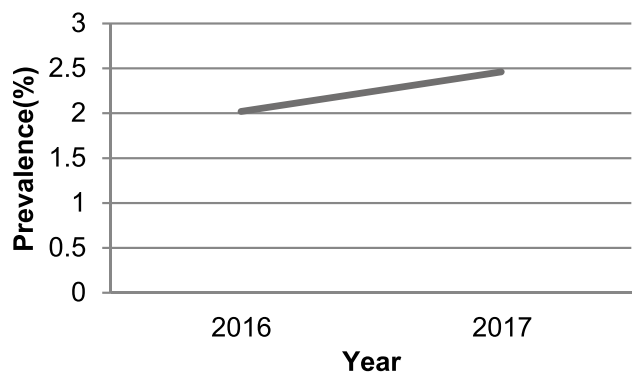

Figure-2

\section{DISCUSSION}

Blood transfusion, being a lifesaving procedure, is very commonly practiced in Pakistan but it is also a source of Transfusion Transmissible Infections (TTIS) with syphilis being one of them. Unscreened blood is one of the most common reasons for its horizontal spread. In our study, out of 76,530 blood donors, 1720 were positive for TP antibody (965 in 2016 and 755 in 2017) with individual and cumulative percentages of these years being $2.46 \%, 2.02 \%$ and $2.25 \%$ respectively.

In previous studies at Lahore, a rising percentage 
of syphilis from $0.19 \%$ to $0.57 \%$ was observed among healthy donors through 1996-2002 with a percentage of $0.48 \%$ during $2005 .^{21}$ Recent studies at Lahore (2012 and 2014) have also suggested a raising percentage of syphilis among healthy donors. ${ }^{15,17}$

This clearly shows an increasing trend which has also been observed in Iran and Cameron. ${ }^{23,24}$ Our study has shown an updated picture of the seroprevalence of syphilis among blood donors of Lahore.

Other cities of Pakistan are also following the same trend e.g. in Karachi, the percentage has increased from $0.22 \%$ to $2.1 \%$ from 2008 to $2015 .{ }^{22,2}$ All the above data has led to a conclusion that percentage of syphilis has increased in previous years. This was due to unsafe sexual practices, decrease in adopting protective measures and improper screening of blood. This challenge has to be faced by our healthcare system which should take measures to reduce it. These include development of proper screening setup, conductance of constant survey and audit to ensure proper use of available resources and increase in economic growth to meet the demanded facilities. In meanwhile, a public awareness is mandatory through seminars, health workers' education, campaigns and media. At public level, younger donors who had never been transfused should be encouraged for blood transfusion. This can drastically reduce the prevalence of syphilis. All this discussion seemed to be fruitful for awareness about severity of situation and important steps to be made.

\section{CONCLUSION}

Percentage of syphilis has increased in year 2016 and 2017 . This needs to be reduced by taking preventive measures and educating the masses. Further work up of the patients who were TP positive is required.

\section{DECLARATIONS SECTION}

\section{Ethics approval and consent to participate}

The study protocols and informed consent documents were approved by the Institutional
Bioethics Review Committee (IBRC).

\section{Consent to publish}

Informed written consent for publication was obtained from each participant.

\section{Availability of data and materials}

The datasets used and/or analyzed during the study are available from the corresponding author on reasonable request.

\section{Competing Interests}

The authors declare that they have no competing interests.

Copyright $(25$ Oct, 2019.

\section{REFERENCES}

1. Allain J-P, Stramer SL, Carneiro-Proietti A, Martins M, Lopes da Silva S,Ribeiro M, et al. Transfusion transmitted infectious diseases. Biologicals. (2009); 37(2): 71-7.

2. Arshad A, Borhany M, Anwar N, Naseer I, Ansari R, Boota $S$, et al. Prevalence of transfusion transmissible infections in blood donors of Pakistan. BMC Hematology. 2016; 16:27. doi:10.1186/s12878-0160068-2.

3. Hutin Y, Kitler ME, Dore GJ, Perz JF, Armstrong,GL, Dusheiko $G$ et al. Global burden of disease (GBD) for hepatitis C. J ClinPharmacol. 2004;44:20-29

4. Bhawani Y, Rao PR, Sudhakar V. Seroprevalence of transfusion transmissible infections among blood donors in a tertiary care hospital of Andhra Pradesh. Biol Med. 2010; 2(4):45-48.

5. Khan S, Attaullah S, Ayaz S, Khan SN, Shams S, Ali I, et al. Molecular epidemiology of HCV among the health care workers of Khyber Pakhtunkhwa. Virol J.2011; 8(1):105.

6. Niqur JM. Blood safety in Pakistan. January-February 1995.WHO/EMRO document WHO-EM/GPA/91/ E/R/05.95/27. Alexandria: World Health Organization Regional Office for the Eastern Mediterranean; 1995.

7. Kazi BM. Standards and guidelines for blood transfusion services. Islamabad: Pakistan National Institute of Health, Federal Health Ministry, Government of Pakistan; 1999.

8. Manzoor I, Hashmi NO, Daud SE, Ajmal SA, Fatima $\mathrm{HI}$, Rasheed ZA, et al. Seroprevalence of transfusion transmissible infections (TTIS) in blood donors. Biomedica. 2009; 25(10):154-8. 
9. Kassi M, Khanani MR, Khan IA, Ali SH. Safe blood transfusion practices in blood banks of Karachi, Pakistan. Transfusion Med. 2011; 21:57-62.

10. Waheed Y, Shafi T, Safi SZ, Qadri I. Hepatitis C virus in Pakistan: a systematic review of prevalence, genotypes and risk factors. World JGastroenterol. 2009; 15(45):5647-5653.

11. Attaullah S, Khan S, Khan J. Trend of transfusion transmitted infections frequency in blood donors: provide a road map for its prevention and control. J Transf Med. 2012; 10(1):1.

12. E. Van Dyck, R. Musonda, L. Zekeng et al. Study Group on Heterogeneity of HIV Epidemics in Zeltser R, Kurban AK. Clin Dermatol. 2004 Nov-Dec; 22(6):4618.

13. Gardella C, Marfin AA, Kahn RH, Swint E, Markowitz LE. Persons with early syphilis identified through blood or plasma donation screening in the United States. J Infect Dis. 2002 Feb 15; 185(4):545-9.

14. Holmes K, Sparling P, Stamm W, Piot P, Wasserheit JN, Corey $L$, et al. Sexually transmitted diseases. 4th ed. New York: McGraw-Hill Medical, 2008.

15. Nazir S,Khan A, Nazar A, Fayyaz A, Khan MS, Ahmed $S$, et al. Prevalence of syphilis in Pakistani blood donors. Adv. life sci. 2013; 1(1):27-30.

16. Waheed $U$, Khan $H$, Satti HS, Ansari MA, Malik MA, Zaheer HA. Prevalence of transfusion transmitted infections among blood donors of a teaching hospital in Islamabad. Ann Pak Inst Med Sci. 2012; 8(4):236-9.

17. Mahmood H, Ansari US,Aslam M, Saeed S, Waqar A. Prevalence of syphilis and HIV infection in blood donors in cosmopolitan Lahore during the year 2014. JUMDC. 2105; 6(4):42-5.
18. Jafri W, Jafri N, Yakoob J, Islam M, Tirmizi SF, Jafar T, et al. Hepatitis B and C: prevalence and risk factors associated with seropositivity among children in Karachi, Pakistan. BMC Inf Dis. 2006; 6(1):1.

19. Ali SA, Donahue RM, Qureshi H, Vermund SH. Hepatitis $B$ and hepatitis $\mathbf{C}$ in Pakistan: prevalence and risk factors. Int J Infect Dis. 2009; 13(1):9-19.

20. Khan ZT, Asim S, Tariq Z, Ehsan MA, Malik RA, Ashfaq $B$, et al. Prevalence of transfusion transmitted infectious in healthy blood donors in Rawalpindi District, Pakistan: A five-year survey. Int J Pathol. 2007; 5(1):21-5.

21. Sultan F, Mehmood T, Tariq M. Infectious pathogens in volunteer and replacement blood donors in Pakistan: A ten-year experience. Int J Infect Dis. 2007; 11 (5):40712.

22. Moiz B, Naseem AS, Khurshid M. Seroprevalence of syphilis in healthy noncommercial blood donors in Karachi. J Coll Physicians Surg Pak. 2006; 16(5):385-6.

23. Khedmat $\mathrm{H}$,Alavian SM, Miri SM, Amini M, Abolghasemi $H$, Hajibeigi $B$, et al. Trends in seroprevalence of hepatitis B, hepatitis C, HIV, and syphilis infections in Iranian blood donors from 2003 to 2005 . Hepat Mon. winter 2009; 9(1):24-8.

24. Noubiap JJN, Joko WYA, Nansseu JRN, Tene UG, Siaka C. Seroepidemiology of human immunodeficiency virus, hepatitis $B$ and $C$ viruses, and syphilis infections among first-time blood donors in Edéa, Cameroon. Int J Infect Dis. 2013 Oct; 17(10):e832-7.

\begin{tabular}{|c|c|c|c|}
\hline \multicolumn{4}{|c|}{ AUTHORSHIP AND CONTRIBUTION DECLARATION } \\
\hline Sr. \# & Author(s) Full Name & Contribution to the paper & Author(s) Signature \\
\hline 1 & Sarmad Zahoor & Writing and analysis. & \\
\hline 2 & Samreen Hameed & Provided expert opinion, & \\
\hline 3 & Waqas Iqbal & $\begin{array}{l}\text { Collaborated in design }+ \\
\text { corresponding manuscript. }\end{array}$ & \\
\hline 4 & Hafeez ur Rehman & $\begin{array}{l}\text { Initiate idea and tall access } \\
\text { it data. }\end{array}$ & Qe \\
\hline 5 & M. Naveed ur Rehman & Supervised data collection. & \\
\hline 6 & Jamil Jaral & Data collection. & \\
\hline
\end{tabular}

